Ks. Antoni ŻUREK

(Tarnów, PAT)

\title{
RELACJE PATRIARCHATU ANTIOCHEŃSKIEGO Z PAPIESKIM RZYMEM W I-IV WIEKU
}

Antiochia była jedną $z$ ważniejszych stolic biskupich od samego początku chrześcijaństwa. Stolica ta odgrywała szczególną rolę na Wschodzie. Relacje biskupa Antiochii $z$ biskupem Rzymem $z$ natury rzeczy należały więc do bardzo istotnych w starożytnym chrześcijaństwie, choć ich pełne wyjaśnienie nie jest latwe ani proste.

\section{ANTIOCHIA CHRZESCIJAŃSKA}

1. Antiochia. Dogodne położenie Antiochii nad Orontesem, zwanej też Antiochią Syryjską, stanowiło jeden $\mathrm{z}$ najważniejszych atutów tego miasta. Założona na 300 lat przed Chrystusem stała się jednym z najbogatszych i najwspanialszych miast Cesarstwa Rzymskiego. Tędy wiodły ważne drogi na Wschód i tu krzyżowały się ważne szlaki handlowe: do Damaszku, Palestyny, Egiptu, na wybrzeża Morza Egejskiego. To czyniło z miasta nie tylko ważny ośrodek wojskowy i handlowy, ale też kulturowy. Urodzajne okolice sprzyjały rozwojowi miejscowej gospodarki, a dobry klimat czynił $z$ miasta pożądane miejsce zamieszkania.

W IV wieku po Chrystusie było to już duże miasto. Historycy nie są zgodni w swoich szacunkach co do liczby mieszkańców. Według szacunków bardziej rygorystycznych mogło ich być około 300 tysięcy $^{1}$. Inni szacują, że 200 tysięcy to była liczba samych dorosłych obywateli bez dzieci i niewolników. Gdyby jednak zliczyć ich wszystkich razem, to w mieście mogło zamieszkiwać nawet około 800 tys. osób ${ }^{2}$. Spośród nich 10 procent stanowili bogacze: kupcy i posiadacze ziemscy, i tyle samo było nędzarzy. Reszta należała do średnio zamoż-

${ }^{1}$ Por. J.W.H.G. Liebeschuetz, Antioch, Oxford 1972, 92-96; G. Downey, Ancient Antioch, Princetown 1968; J.A. Festugière, Antioche païenne et chrétienne, Paris 1969; DHGE III 563-703; DPAC I 228-246.

${ }^{2}$ Por. J. Kollwitz, Antiochia am Orontes, RACh I 462. 
nych $^{3}$. Pod tym względem, jak się wydaje, był to układ korzystniejszy niz w większości rzymskich miast. Chociaż językiem urzędowym był język grecki, to większość mieszkańców było pochodzenia syryjskiego. Były też inne mniejszości, wśród nich znacząca mniejszość żydowska, ale „wszystkie te grupy mieszały się w najróżnorodniejszy sposób" ". Grecki też był charakter miasta, a ton nadawali mu tam żyjący i działający znani ludzie, kultywujący greckie tradycje.

Miasto było ładnie $\mathrm{i}$ bogato urządzone. Zgodnie $\mathrm{z}$ wiarygodnymi świadectwami „Główna ulica wybrukowana była marmurem, upiększona dwupiętrowymi kolumnadami i nocą oświetlona lampami oliwnymi [...] zasłużenie szczyciła się wspaniałymi budynkami, rozbudowanym systemem wodociągów i licznymi łaźniami (w sumie było ich 18 , po jednej dla każdej $z$ dzielnic), teatrami i hipodromem"s. Już na długo przed Chrystusem w mieście była wielka biblioteka publiczna, działały szkoły i uczyli słynni nauczyciele ${ }^{6}$. Architektura Antiochii musiała budzić podziw, skoro w IV wieku po Chrystusie uchodziła za „najpiękniejszy klejnot Wschodu" naczali się swoistym charakterem. Jak zapisze kronikarz tamtych czasów, lud Antiochii „,był $z$ natury miłośnikiem widowisk, oddany raczej wygodnemu życiu niż ciężkim trudom"8. Antiocheńczycy wyróżniali się zamiłowaniem do wyścigów konnych i teatru, a także niepokornym duchem ${ }^{9}$.

Metropolia ta pełniła także funkcje strategiczne, ważne dla całego państwa rzymskiego; otoczona blisko 10 kilometrowymi murami, mogła uchodzić za miasto warowne. Tym bardziej, że była siedzibą władz wojskowych i administracyjnych. Rezydował tam konsul prowincji Syria, ale też komes Orientu, rozległej „diecezji, która za panowania Walensa (364-378) obejmowała 15 prowincji i rozciągała się od Mezopotamii do granic Egiptu"10. W mieście stacjonował garnizon wojskowy i rezydował komendant wojskowy na obszar Orientu. Do miasta chętnie przybywali liczni dostojnicy, z cesarzami na czele, tym bardziej, ze tym ostatnim zawsze było tam po drodze, gdy wyruszali na Wschód bronić granic Cesarstwa. Były też okresy, gdy miasto stawało się przejściową rezydencją cesarską.

Antiochia była również znanym ośrodkiem religii pogańskiej. W samym mieście i na jego obrzeżach istniało wiele świątyń poświeconych popularnym bóstwom. Jeszcze w IV wieku istniało tam podobno sześć świątyń pogańskich,

${ }^{3}$ Tak szacowal Jan Chryzostom, por. In Matthaeum hom. 66, 3.

4 Por. J. Kollwitz, dz. cyt., s. 462.

5 J.N.D. Kelly, Zlote usta. Jan Chryzostom, thum. K. Krakowczyk, Bydgoszcz 2001, 13.

${ }^{6}$ Por. Eusebius, HE VII 29. Szerzej zob. E. Johnson, Słownik wiedzy biblijnej, Warszawa $1997,15$.

7 Ammianus Marcellinus, Res gestae XXII 9, 14, tłum. I. Lewandowski, Warszawa 1998, 409.

8 Zosimos, Nova historia III 11, 4, tłum. H. Cichocka, Warszawa 1993, 134.

${ }^{9} \mathrm{~Np}$. pozwalali sobie na kpiny z cesarza Juliana i kwestionowali sensowność jego rozporządzeń, por. Ammianus Marcellinus, Res gestae XXII 14, 3nn.

${ }^{10}$ Kelly, dz. cyt., s. 14. 
a kilka kilometrów od miasta była słynna świątynia Dafne, poświęcona Apollinowi, wybudowana blisko dwieście lat przed Chrystusem. W samej Antiochii żywy był też kult Adonisa ${ }^{11}$. Nie bez racji cesarz Julian próbował właśnie w tym mieście odnowić starożytne kulty. Pożar świątyni w Dafne, o który usiłował oskarżyć chrześcijan, w dużej mierze przyspieszył upadek kultu pogańskiego na tym terenie ${ }^{12}$. Dłużej przeżyły popularne wśród ludności wiejskiej kulty syryjskie. Zwalczał je m.in. Jan Chryzostom, ale jeszcze w VI wieku spotkać można bylo ich ślady ${ }^{13}$.

2. Chrześcijaństwo w Antiochii. Chrześcijanie pojawili się w Antiochii bardzo wcześnie. Męczeństwo Szczepana zmusiło wielu chrześcijan do ucieczki z Jerozolimy. Wielu z nich szukało schronienia w Antiochii, gdzie dali początek nowej gminie ${ }^{14}$. Do Antiochii przybył również z Jerozolimy Barnaba, który dobrawszy sobie do pomocy Pawła, prowadził w mieście ożywioną działalność apostolską. Chrześcijańska wspólnota szybko się w Antiochii zadomowiła i zaczęła zyskiwać wyznawców także wśród pogan. Dzięki temu gmina antiocheńska została wkrótce zdominowana przez „hellenistów”, co z kolei doprowadziło do poważnych napięć, u podłoża których leżały kwestie przestrzegania zwyczajów żydowskich przez nowo ochrzczonych ${ }^{15}$. Sprawą musiał się zająć sobór w Jerozolimie. Chrześcijanie z Antiochii z dumą wspominali, że to właśnie tam po raz pierwszy wyznawców Chrystusa nazwano chrześcijanami ${ }^{16}$.

W Antiochii przebywał też przez jakiś czas św. Piotr, przed swoim udaniem się w stronę Rzymu. Według tradycji wczesnochrześcijańskiej, potwierdzonej przez Euzebiusza, uchodził on za pierwszego biskupa tego miasta ${ }^{17}$. Z jego pobytem związany jest spór, o którym wspomina św. Paweł ${ }^{18}$. Dla tego ostatniego Antiochia stała się miejscem, z którego inicjował swoje podróże misyjne.

Następne dziesięciolecia są mało udokumentowane. Wprawdzie Euzebiusz zamieszcza imiona biskupów tego miasta, ale mało o nich pisze. Najsłynniejszym $\mathrm{z}$ nich był niewątpliwie jeden z pierwszych biskupów tego miasta Ignacy, który zginął jako męczennik na początku II wieku. Znany był też Teofil, autor apologii skierowanej do cesarza Kommodusa. Słynnym, choć może z nie najlepszej strony, był również Paweł z Samosaty, biskup Antiochii i herezjarcha, którego sprawę rozpatrywały synody w 2 . poł. III wieku.

\footnotetext{
1 Por. Ammianus Marcellinus, Res gestae XXII 9, 15.

12 Por. tamże XXII 13.

13 Por. Kollwitz, dz. cyt, s. 463.

14 Por. Dz 11, 19.

${ }^{15}$ Szerzej zob. É. Trocmé, Pierwsze kroki chrześcijaństwa, tłum. J. Gorecka-Kalita, Kraków 2004, 55- 56.

${ }^{16}$ Por. Dz 11, 19-26.

17 Por. Eusebius, HE III 36, 2.

18 Por. Gal 2, 11-14.
} 
W III wieku Antiochia stała się głośna w związku z pobytem w niej Orygenesa ${ }^{19}$, działalnością wyżej wspomnianego Pawła z Samosaty ${ }^{20}$ oraz odbywających się tam synodów, a także działających w niej słynnych już chrześcijańskich uczonych.

W czasach Dioklecjana w Antiochii miało miejsce prześladowanie chrześcijan. W samym mieście zburzono kościół, a ofiarami byli zarówno Antiocheńczycy, jak też chrześcijanie z okolic, którzy znaleźli się w mieście. Wśród nich był m.in. diakon Roman ${ }^{21}$, a także bohaterskie chrześcijanki oraz okoliczni duchowni ${ }^{22}$. Śmiercią męczeńską za Maksymiana zginął Lukian „mąż pod każdym względem znakomity, słynny z życia powściągliwego i biegłości w świętych naukach"23. Chwile grozy przeżyli jeszcze potem chrześcijanie w Antiochii za czasów cesarza Juliana, który usiłował obarczyć ich winą za podpalenie świątyni Apollina ${ }^{24}$.

Od czasów pokoju konstantyńskiego gmina antiocheńska rozwijała się dynamicznie. Rosła liczba chrześcijan w samym mieście, tak że pod koniec IV wieku stanowili oni większość mieszkańców. Masowy przyrost liczby chrześcijan nie zawsze szedł w parze $z$ poziomem życia przez nich reprezentowanym. Słuchając kazań i katechez św. Jana Chryzostoma można odnieść wrażenie, że wielu chrześcijan dość powierzchownie traktowało wymagania stawiane im przez wiarę. Dla tak wielkiej liczby chrześcijan trzeba było wznosić stosowną liczbę budynków sakralnych. Dostępne nam źródła wymieniają kilka kościołów, co wcale nie oznacza, że wszystkie. Wśród nich najbardziej okazały był „Wielki Kościół”, którego budowę rozpoczął Konstantyn Wielki, a zakończył jego syn Konstancjusz. Jego poświęcenie (,in Encaeniis") w 341 r. odbiło się głośnym echem w świecie chrześcijańskim ${ }^{25}$. Być może pełnił on rolę katedry ${ }^{26}$. Do kościołów usytuowanych w mieście dodać należy kaplice zbudowane na grobach męczenników, których w tych okolicach było dużo ${ }^{27}$.

Powstawały i rozwijały się też różne instytucje związane $\mathrm{z}$ działalnością Kościoła. Wśród nich na pierwszym miejscu należy wymienić słynną „szkołę antiocheńską", której nieformalnym założycielem był wspomniany Lukian ${ }^{28}$. Obok niego działali tu też inni znani i oryginalni uczeni, jak Doroteusz i Mal-

${ }^{19}$ Odbywać tam miał dysputy religijne z cesarzową Julią Mammeą, por. Eusebius, HE VI 21.

20 Por. Eusebius, HE VII 27-30.

${ }^{21}$ Por. Eusebius, De martyribus Palaestinae 2. Roman był diakonem Kościola w Cezarei, a w Antiochii znalazł się przypadkowo.

22 Por. Eusebius, HE VIII 12, 3; 13, 2.

${ }^{23}$ Tamzie IX 6, 3, SCh 55, 52, POK 3, 398.

24 Por. Ammianus Marcellinus, Res gestae XXII 13.

25 Por. Theodoretus, HE III 8.

26 Por. O. Pasquato, DPAC I 229.

27 Por. Kelly, dz. cyt., s. 15.

28 Szerzej zob. M. Simonetti, Antiochia di Siria. Scuola, DPAC I 241-242. 
chion $^{29}$. W IV stuleciu grono osób związanych $\mathrm{z}$ tą szkołą było duże. Wśród nich było wiele znanych osobistości życia teologicznego, jak też biskupów i duszpasterzy ${ }^{30}$. Kościół instytucjonalny, posiadający już znaczny majątek, prowadził dzieła dobroczynne ${ }^{31}$. Nie ulega wątpliwości, że tak chrześcijaństwo, jak też teologia antiocheńska miała swoją specyfikę, a sama Antiochia stanowiła „oryginalne centrum kultury chrześcijańskiej”32.

Najboleśniejszym wydarzeniem dla Kościoła antiocheńskiego IV wieku była tzw. schizma antiocheńska ${ }^{33}$. Jej podłożem były spory, jakie wybuchły po Soborze Nicejskim. Cała historia rozpoczęła się na zwołanym w kilka lat po Nicei synodzie w Antiochii, gdzie złożono z urzędu pronicejskiego biskupa Eustacjusza $^{34}$. Decydujący głos od tej chwili mieli biskupi filoariańscy, a wspólnota chrześcijańska w Antiochii podzieliła się na stronnictwa. Podziały te utrzymywały się przez kilkadziesiąt lat. Najtragiczniejsze były lata sześćdziesiąte, kiedy to w mieście było aż trzech biskupów. Zaprowadzenie jedności i pokoju w tym lokalnym Kościele stało się sprawą całego Kościoła ${ }^{35}$. Rozłamy wreszcie się zakończyły, choć ich ślady w świadomości mieszkańców musiały jeszcze długo być dostrzegalne ${ }^{36}$.

3. Patriarchat antiocheński. Same początki instytucji patriarchatu, w tym także antiocheńskiego, nie są do końca wyjaśnione. $Z$ całą pewnością był to proces ewolucyjny, a wpływ na samo powstanie i rozwój tej instytucji miały różne czynniki. Istotną rolę odegrały tu z pewnością względy czysto naturalne i praktyczne. Kościół nad tym rozwojem czuwał i go ukierunkowywał, dostrzegając w tej instytucji dobro i pożytek.

Antiochia stanowiła w sposób naturalny centrum chrześcijaństwa dla całego regionu. Jej rola była tym większa, że stał za nią autorytet św. Piotra, który według późniejszej tradycji był nawet jej pierwszym biskupem ${ }^{37}$. W tym sensie zasługiwała ona na miano stolicy apostolskiej. Ważniejsza, jak się wydaje, była

${ }^{29}$ Kapłan Malchion „mial równocześnie powierzone sobie nauczanie retoryki w szkołach Antiochii”, por. J. Daniélou - H.I. Marrou, Historia Kościoła, t. 1, tłum. M. Tarnowska, Warszawa $1986,171$.

${ }^{30}$ Szerzej zob. H. Langkammer, Antiocheńska szkota egzegetyczna, EK I 647.

31 Por. Kelly, dz. cyt., s. 66.

32 Daniélou - Marrou, dz. cyt., s. 171.

${ }^{33}$ Szerzej zob. M. Simonetti, Antiochia di Siria, DPAC I 237-238; F. Cavallera, Le schisme d'Antioche, Paris 1905.

34 Stało się to w latach 330-333, por. M. Simonetti, La crisi ariana nel $\mathrm{W}$ secolo, Roma 1975, 103.

35 Por. Basilius, Epistola 66, 2, SCh 32, 425, tłum. W. Krzyżaniak: Św. Bazyli Wielki, Listy, Warszawa 1972, 105: „cóż dla Kościołów całej ziemi jest bardziej żywotne niż Antiochia?”.

${ }^{36}$ Daniélou - Marrou, dz. cyt., s. 205: „Kryzys rozpoczęty przez zlożenie z urzędu Eustacjusza miał trwać 85 lat".

37 Jako pierwszy wspomina o tym Orygenes: In Lucam hom. 6, 4, SCh 87, 144, PSP 36, 45: "Ignacego drugiego po Piotrze biskupa Antiochii". 
jednak rola, jaką w chrystianizacji regionu odegrał Kościól antiocheński. „Wybitna działalność misyjna Antiochii musiała przyczynić się do rozszerzenia jej wpływów na te tereny [...]. Można słusznie przypuszczać, że Antiochia dlatego stała się centrum misyjnym dla sąsiednich terenów, ponieważ miała silną i aktywną gminę, rozporządzającą [już w czasach apostolskich - przyp. autora] tak wybitnymi misjonarzami, jak Paweł i Barnaba" ${ }^{38}$. Szybki rozwój chrześcijaństwa w tym mieście powodowal, że to z tego ośrodka promieniowało ono na cały region. Jako duży ośrodek chrześcijański oddziaływała na bliższe i dalsze regiony Syrii. Nie bez znaczenia była też ranga cywilna tego miasta.

Namacalnym tego wyrazem były synody, jakie odbywały się w tym regionie. Już w III wieku na synodach w Antiochii gromadzili się liczni biskupi z calego regionu. Fakt, że uczestnikami tych synodów „byli zawsze reprezentanci tych samych terenów, jak Azja Mniejsza [...] Syria i Palestyna, wskazuje na pewno, że Antiochia stanowila centrum grawitacyjne tych terenów"39. Przewodzili im biskupi antiocheńscy, których do tej roli predysponowały nie tylko walory osobiste, ale przede wszystkim spełniana funkcja. Podobną rolę spełniali oni zresztą na innych synodach, odbywających się na terenie patriarchatu ${ }^{40}$. Synody te gromadziły bardzo dużą liczbę biskupów, co świadczy nie tylko o rozległych wpływach Antiochii, ale też o gęstej sieci biskupstw w tej części Kościoła.

W jeszcze większym stopniu Antiochia stała się stolicą regionu w IV wie$\mathrm{ku}^{41}$. Obrady synodalne gromadziły po kilkudziesięciu biskupów, podejmowano tam decyzje mające duże znaczenie dla całego regionu. Natomiast przyjmowane uchwały, związane $\mathrm{z}$ toczącymi się wówczas sporami trynitarnymi, miały wymowę ogólnokościelną ${ }^{42}$. Biskup Antiochii, nawet bez specjalnego mandatu, cieszył się autorytetem i miał decydujący głos wśród swoich współbraci, niezależnie od swoich preferencji doktrynalnych. W ten sposób powoli kształtowała się tradycja patriarchatu. Po raz pierwszy zauważono to w sposób oficjalny na Soborze Nicejskim, którego kanon 6 brzmi:

„Starożytny zwyczaj niech będzie zachowany w Egipcie, Libii i Pentapolis, zgodnie z którym biskup aleksandryjski posiada wladzę nad tymi wszystkimi prowincjami, tak jak i biskupowi Rzymu przysługuje podobny zwyczaj. Podobnie ma się rzecz w odniesieniu do Antiochii i innych prowincji: niech będzie zachowane w Kościolach pierwszeństwo wynikające ze starszeństwa" ${ }^{\text {,43 }}$.

\footnotetext{
${ }^{38}$ E. Przekop, Wschodnie patriarchaty starożytne ( $V-X$ wiek), Warszawa 1984, 52-53.

${ }^{39}$ Tamże, s. 53.

${ }^{40}$ Por. L. Lahm, Le patriarcat d'Antioche au premier millenaire, w: I patriarcati orientali nel primo millenio, OCA 181, Roma 1968, 115-136, spec. 117.

${ }^{41}$ Szerzej zob. M. Simonetti, Antiochia di Siria. Concili, DPAC I 233-235.

42 Szerzej zob. J. Dudziak, Synody antiocheriskie, EK I 654.

43 Concilium Nicaenum I, can. 6, thum. A. Baron, w: Dokumenty Soborów Powszechnych. Tekst grecki, laciński, polski, t. 1: (325-787), red. A. Baron-H. Pietras, ŹMT 24, Kraków 2001 (= DSP I), 33 .
} 
Kanon w sposób dość ogólny przyznaje biskupowi Antiochii bliżej niesprecyzowane uprawnienia. Niejasny jest przede wszystkim zakres wladzy patriarchy, wynikający z jego pierwszeństwa. Jak się wydaje „są jednak podstawy, by sądzić, że biskup antiocheński miał wobec wszystkich biskupów Wschodu prymat będący czymś więcej, niż tylko wyróżnieniem honorowym, którego jednak historyk nie potrafi dzisiaj dokładnie określić"44. Gdyby ta władza była analogiczna do władzy patriarchy aleksandryjskiego, to jej zakres byłby duży, ale brak na to przekonywujących dowodów. Kanon soborowy nie wyjaśnia też, skąd się wywodzi i co oznacza owo "starszeństwo" Antiochii. Jest mowa tylko o „starożytnym zwyczaju”. Następne dziesięciolecia będą do tego dodawać nowe wątki. W dokumentach Soboru w Konstantynopolu jest mowa $\mathrm{z}$ kolei o „najstarszym i prawdziwie apostolskim Kościele w Antiochii Syryjskiej”45. „Dopiero w V wieku, a więc wtedy, gdy patriarchat Antiochii był już faktem dokonanym, biskupi antiocheńscy, uzasadniając swoje prawa i przywileje, zaczęli powoływać się na Piotrową sukcesję" ${ }^{\text {46. }}$

Dyskutowana i nie do końca wyjaśniona jest też terytorialna rozległość patriarchatu antiocheńskiego. Są autorzy, którzy rozciągają tę władze bardzo szeroko, nawet poza granice Cesarstwa ${ }^{47}$. Według innych, w granicach patriarchatu znajdowały się terytoria przynależne do kilku prowincji Wschodu, ale w granicach Cesarstwa ${ }^{48}$. Sobór w Konstantynopolu (381) potwierdzając decyzje Nicei określa wpływy Antiochii do „diecezji Orientu”49. W każdym bądź razie, w IV wieku patriarchat antiocheński obejmowal ponad 10 metropolii i dużo ponad 100 sufraganii $^{50}$. Granice patriarchatu kształtowały się nie na mocy odgórnych decyzji administracyjnych, ale były „owocem wewnętrznego rozwoju hierarchicznego i kościelnego, w którym najważniejsze role odegrały względy praktyczne, etniczne i geograficzne" ${ }^{\prime 5}$. Począwszy od V wieku, na skutek różnych czynników, patriarchat ten zaczął się kurczyć. Przyczynił się do tego najpierw wzrost znaczenia Konstantynopola ${ }^{52}$, a potem podziały i powstawanie Kościołów narodowych, co miało miejsce zwłaszcza po Soborze w Chalcedonie ${ }^{53}$.

${ }^{44}$ Przekop, dz. cyt., s. 28.

45 Epistula Constantinopolitani Concilii ad papam Damasum et occidentales episcopos 8, thum.

T. Wnętrzak, DSP I 85.

46 Przekop, dz. cyt., s. 55.

47 Por. B. Kumor, Antiochia. Patriarchaty, EK I 649.

${ }^{48}$ Lahm, dz. cyt., s. 117-118.

49 Por. Concilium Constantinopolitanum 1, can. 2, tłum. T. Wnętrzak, DSP I 73.

${ }^{50}$ B. Kumor mówi nawet o 250 biskupstwach, por. EK I 649.

51 Lahm, dz. cyt., s. 119.

52 Por. Przekop, dz. cyt., s. 30nn.

53 Por. tamże, s. 38nn. 


\section{ANTIOCHIA I RZYM}

Wzajemne i oficjalne relacje między Rzymem a Antiochią w pierwszych czterech stuleciach są tylko częściowo udokumentowane i sprowadzają się do poszczególnych przypadków, w które zaangażowane były obie stolice.

1. W okresie przednicejskim. Euzebiusz z Cezarei w swojej Historii kościelnej w sposób bardziej szczegółowy i systematyczny relacjonuje fakty związane $\mathrm{z}$ kilkoma stolicami biskupimi; jedną $\mathrm{z}$ nich jest Antiochia. $\mathrm{Z}$ zadziwiającą skrupulatnością podaje imiona kolejnych biskupów tego miasta, nawet wtedy, gdy ma o nich niewiele lub nic do powiedzenia. Nie ulega wątpliwości, że nie dzieje się tak ani z czystego przypadku, ani też dlatego, że było to miasto bliskie mu geograficznie. Antiochia była znaczącym i wpływowym miastem, biskup tego miasta wywierał duży wplyw na życie Kościoła w całym regionie. Nie uzasadniano tego żadnym pisanym czy stanowionym prawem, ale na mocy niepisanej tradycji.

W świecie chrześcijańskim było kilka stolic biskupich cieszących się podobnym prestiżem. Do takich z całą pewnością należał także Rzym i Aleksandria. Wyrazem wzajemnego szacunku była wymiana listów między biskupami tych stolic, informowanie się o sytuacji wewnętrznej, zwłaszcza w przypadku pojawiających się trudności. W sytuacjach kryzysowych szukano wsparcia. W przypadku Antiochii uprzywilejowanym partnerem do takich kontaktów była Aleksandria. Na początku 2. poł. III wieku zaistniała nowa sytuacja: nastąpiła intensyfikacja kontaktów z Rzymem. Najpierw przyczyną stał się Nowacjan: gdy jego sprawa wybuchła w Rzymie, biskup tego miasta Korneliusz poinformował o całej sprawie biskupa Antiochii Fabiana ${ }^{54}$. Ponieważ Nowacjan próbował szukać poparcia w Antiochii, Dionizy z Aleksandrii przestrzegał tamtejszy Kościół przed takim gestem. $Z$ jego zaś listów można wnioskować, że „odgrywal on rolę mediatora między Rzymem a Antiochią, co stanie się jedną z tradycji Kościoła egipskiego w przyszłych wiekach" "55. Listy te mieszczą się, jak się wydaje, w ówczesnej praktyce i nie ma w nich mowy o wzajemnych zależnościach poszczególnych stolic.

Odmiennie natomiast przedstawiała się historia Pawła z Samosaty, biskupa Antiochii. Decyzją synodu zwołanego do Antiochii w 261 r. został on usunięty $z$ urzędu za szerzenie błędnej doktryny. Decyzję tę wraz z wyjaśnieniem przesłano specjalnym listem „Dionizemu, biskupowi rzymskiemu, oraz Maksymusowi aleksandryjskiemu", jak też wszystkim prowincjom ${ }^{56}$. W liście tym nie ma uzasadnienia, dlaczego tych właśnie adresatów wymieniono z imienia. Moty-

${ }^{54}$ Por. Eusebius, HE VI 43, 3.

55 Daniélou - Marrou, dz. cyt., s. 169.

56 Por. Eusebius, HE VII 30, 1, SCh 41, 214, POK 3, 345. 
wów można się jednak domyślać. W liście jest tylko zawarta informacja, a w zakończeniu prośba o przyjęcie listów uwierzytelniających od następcy Pawła z Samosaty ${ }^{57}$. Zwykła informacja, poniekąd gest protokolarny, zważywszy, że podobne listy pisano przy powołaniu każdego biskupa. Natomiast sam Euzebiusz dołącza bardzo interesującą informację. Złożony z urzędu Paweł nie chciał opuścić mieszkania kościelnego. Strona kościelna skierowała zatem zażalenie do cesarza Aureliana. Ten zaś „,kazał przyznać dom tym, którym go biskupi italscy i miasta Rzymu oddać polecą" ${ }^{158}$. Gest znamienny, ale wymowa jego trudna do wyjaśnienia, tym bardziej, że brak bardziej szczegółowych informacji. Można pytać, czy chodziło o gest grzecznościowy ze strony cesarza, czy też w oczach cesarza ci biskupi cieszyli się większym autorytetem, a może $z$ urzędowej perspektywy biskup rzymski miał nie tylko większe znaczenie niż antiocheński, ale wręcz uchodził za jego przełożonego. Na te pytania trudno znaleźć satysfakcjonującą odpowiedź.

2. Kryzys antiocheński. Kontakty Antiochii z Rzymem zintensyfikowały się po Soborze Nicejskim, zwłaszcza w okresie wspomnianego już kryzysu antiocheńskiego. Bezpośrednią przyczyną jego powstania były spory doktrynalne, związane $\mathrm{z}$ orzeczeniami Soboru. Formalnie jednak poszło o sprawy personalne. Silne stronnictwo fioloariańskie postanowiło usunąć z urzędu biskupa Antiochii Eustacjusza, „nieprzejednanego przeciwnika arian" ${ }^{\text {. }}$. Naraziwszy się temu stronnictwu zaledwie kilka lat po Nicei, został fałszywie oskarżony na zwołanym w Antiochii synodzie, któremu przewodniczył Euzebiusz z Cezarei. Synod ten uznal go winnym stawianych mu zarzutów o charakterze dyscyplinarnym, a nie doktrynalnym. Na jego miejsce został wybrany Eufroniusz ${ }^{60}$. Takich zmian dokonano także na innych stolicach.

Usunięci biskupi udali się szukać pomocy w Rzymie. Papież Juliusz rozpoznał ich sprawę, uznał bezpodstawność zarzutów „a ponieważ do niego należała troska nad całością, a to ze względu na godność tronu, oddał przeto każdemu własny jego Kościół",61. Biskup Juliusz zredagował list do wszystkich biskupów Wschodu, w tym także Antiochii, w którym nie tylko nakazał przywrócić usuniętych biskupów, ale zagroził „że nie okaże się pobłażliwym na przyszłość, jeśli natychmiast nie zaprzestaną swej wywrotowej działalności"62.

Inicjatywa biskupa Rzymu, relacjonowana przez Sozomena, wyplywa, jak się wydaje, z przekonania o posiadanych prerogatywach, jakkolwiek nie zos-

\footnotetext{
57 Por. tamże VII 30, 17.

58 Tamże VII 30, 19, SCh 41, 219, POK 3, 350.

59 M. Simonetti, Eustazio di Antiochia, DPAC I 1301. Synod odbył się w 327 roku.

60 Por. Sozomenos, HE II 19.

61 Tamże III 8, PG 67, 1052CD, thum. S. Kazikowski: Sozomen, Historia Kościola, Warszawa

62 Tamże.
} $1989,164$. 
tało wspomniane, z czego one wynikaja. Adresatem listu rzymskiego biskupa Juliusza byli biskupi Wschodu, ale w praktyce odnosiło się to do biskupów „Zebranych w Antiochii" ${ }^{23}$, choć ich faktycznym przywódcą był Euzebiusz z Nikomedii, a nie aktualny biskup tego miasta ${ }^{64}$.

Przedstawiciele Wschodu, a przede wszystkim Euzebiusz z Nikomedii, odmówili zgody na rewizję wyroków. Zebrani w Antiochii ułożyli w odpowiedzi list „w pewnym sensie wytworny, a zarazem chytrze przemyślany i za każdym zdaniem pełnym ironii" ${ }^{65}$. Wprawdzie uznano tam autorytet Rzymu, ,jako szkoły myśli apostolskiej"66, ale przez to autorzy listu nie czuli się wcale niżsi. Sugerują adresatowi, by zachował się analogicznie do zachowania biskupa Antiochii $w$ sprawie Nowacjana, kiedy to po prostu na Wschodzie przyjęto decyzję Rzymu w jego sprawie do wiadomości i z nią się pogodzono. Podobnego zachowania ze strony Rzymu oczekiwano w Antiochii, po decyzjach tam podjętych w sprawie Atanazego i innych biskupów. Uchwały synodu antiocheńskiego z 341 r. wyrażają właśnie takie oczekiwania. Tym samym wystąpienie biskupa Rzymu w roli arbitra zlekceważono i poczytano jako „niewłaściwe wtrącanie się potężnego biskupa Zachodu w wewnętrzne kwestie Kościołów wschodnich" $"$ "

Bardzo interesująca i wymowna jest $z$ kolei reakcja biskupa Juliusza. Zredagował obszerny list, w którym ustosunkowal się do zaistniałej sytuacji. Historycy, m.in. Sokrates i Sozomen, podają jego najważniejsze myśli. W piśmie tym Juliusz zarzuca biskupom ,zebranym w Antiochii” potajemne wprowadzanie zmian w wyznaniu wiary $z$ Nicei, a przede wszystkim, że „wbrew prawom Kościoła nie wezwali go na synod". Powoływać się miał przy tym na „istnienie obowiązującego kapłanów prawa, że wszelkie posunięcia dokonane wbrew woli biskupa rzymskiego należy uznawać za nieważne" ${ }^{68}$. Można pewnie wnioskować, że tak te zarzuty odebrano. Ponieważ tekst interesującego nas w tej chwili listu przytacza Atanazy, można więc tam szukać wskazanych treści, a zwłaszcza sformułowań ${ }^{69}$.

Biskup Rzymu najpierw ubolewa nad brakiem szacunku do niego i jego inicjatywy. Następnie powołuje się na sobór w Nicei i jego ustalenia, by w przypadku rozstrzygania spraw personalnych na każdym kolejnym synodzie

${ }^{63}$ Tamże.

${ }^{64}$ Szerzej zob. Simonetti, La crisi ariana, dz. cyt., s. $145 \mathrm{nn}$.

65 Sozomenos, HE III 8, Kazikowski s. 164.

66 Tamże.

67 Simonetti, La crisi ariana, dz. cyt., s. 150.

68 Sozomenos, HE III 10, PG 67, 1057, Kazikowski s. 168. Sokrates natomiast pisze o „naruszeniu obowiązujących kanonów, ponieważ nie zaprosili go na synod, mimo że prawo kanoniczne wyraźnie zabrania Kościolom podejmowania uchwały bez zgody ze strony biskupa Rzymu" (HE II 17, thum. S. Kazikowski, Warszawa 1986, 178).

69 Tekst listu w: Athanasius, Apologia contra Arianos 21-35, PG 25, 281-309, tlum. J. Ożóg, PSP 21, 111-122. 
czytać dokumenty poprzedniego celem pełnego poznania sprawy. Po omówieniu wypadków związanych $\mathrm{z}$ usunięciem $\mathrm{z}$ urzędu Atanazego przechodzi do przedstawienia swego stanowiska w tej sprawie. Przedstawia siebie jako reprezentanta „wszystkich biskupów Italii"70 oraz obrońcę „prawa kościelnego", który miał prawo przyjąć do wspólnoty biskupa Atanazego i unieważnić tym samym wyrok synodu w Tyrze, ze względu na braki dowodowe i proceduralne uchybienia $^{72}$. Następnie zarzuca adresatom swego listu z Antiochii lamanie „prawa kościelnego”, występowanie „wbrew praktyce Kościola” i brak ,apostolskiego nakazu” jako podstawy działania ${ }^{73}$. Przy czym „przykazaniem apostolskim” nazywa zasadę powoływania na stolicę biskupią „,kogoś z miejscowego duchowieństwa” i konsekrowania go przez „biskupów tej samej prowincji”74. Po tym następują polecenia naprawienia błędnych decyzji, zaprowadzenia pokoju i powiadomienia o tym biskupa Rzymu. Biskup Juliusz przypomniał:

„Trzeba było napisać do nas wszystkich, żeby wszyscy biskupi mogli postanowić to, co shuszne. Cierpieli bowiem biskupi i nie jakiekolwiek Kościoły, lecz te, którym przewodzili sami apostołowie [...]. Czyż nie wiecie, że jest taki zwyczaj, że najpierw pisze się do nas i dopiero my stanowimy to, co słuszne? [...] trzeba było napisać o tym do tutejszego Kościoła. Tymczasem nie dość, że nas nie zawiadomili i na własną rękę robili, co się im podobała, to chcą ponadto, żebyśmy się opowiedzieli po ich stronie. Nie takie są postanowienia Pawla, nie to przekazali nam Ojcowie [...]. Proszę was, znieście to ochotnie [...]. Mówię wam przecież to, co otrzymaliśmy od błogosławionego Piotra Apostoła"75.

Jak widać, biskup Juliusz jest przekonany o swoim autorytecie, pochodzącym od Piotra oraz $z$ utrwalonych już zwyczajów Kościoła. W liście pojawia się też wzmianka o apostolskim pochodzeniu innych stolic: tu Aleksandrii. Taka była perspektywa biskupa Rzymu. O ile nam wiadomo, stanowisko papieża Juliusza, tak dobitnie wyrażone, nie zmusiło Antiocheńczyków do zmiany ich stanowiska.

3. Schizma antiocheńska. W Antiochii od chwili złożenia z urzędu biskupa Eustacjusza biskupów namaszczali filoarianie lub arianie. W ten sposób w 360 r. biskupem został Melecjusz. Wkrótce jednak stracil zaufanie swojego stronnictwa, bo przeszedł na stronę zwolenników Nicei i w związku z tym został przez swoich dotychczasowych zwolenników usunięty $z$ urzędu i zesłany do Armenii. Na jego miejsce wybrano nowego biskupa Euzojosa. Prawie równocześnie na czele ortodoksyjnej grupy chrześcijan stanąl Paulin, który został

\footnotetext{
${ }^{70}$ Apologia 26, PG 25, 292C, PSP 21, 116.

71 Apologia 29, PG 25, 297A, PSP 21, 118.

72 Por. Apologia 27-28, PG 25, 292-296, PSP 21, 116-117.

73 Apologia 30, PG 25, 297BC, PSP 21, 118.

74 Tamże.

75 Apologia 35, PG 25, 308, PSP 21, 122.
} 
wyświęcony na biskupa przez Lucyferiusza z Kalaris. Na początku 362 r. Melecjusz powrócił i w ten sposób w Antiochii było trzech biskupów, urzędujących w trzech kościołach ${ }^{76}$.

Kościoły Zachodu od pierwszej chwili uznały ważność wyboru i święceń Paulina i konsekwentnie przy tym obstawały. Poszkodowanym w tym względzie był przede wszystkim Melecjusz, który nie tylko, że w świetle prawa był legalnym biskupem Antiochii, ale był też zwolennikiem ortodoksji. Swoje stanowisko w kwestiach wiary zademonstrował na zwołanym w Antiochii synodzie (363), gdzie przyjęto credo zgodne z nauką Soboru Nicejskiego. Wraz z uchwałami podobnych synodów wysłano te dokumenty do Rzymu i do innych biskupów łacińskich ${ }^{77}$. Papież Liberiusz $\mathrm{z}$ radością i uznaniem przyjął przesłane deklaracje, ale swego poparcia dla Paulina nie wycofał. Nie uczynił tego również nawet wtedy, gdy Melecjusz stał się niekwestionowaną "glową episkopatu Wschodu" i ciesząc się poparciem Bazylego Wielkiego przewodził koalicji antyariańskiej ${ }^{78}$. Również formalna zgoda zawarta $z$ Paulinem nie wpłynęła na zmianę jego sytuacji. Tak pozostało aż do śmierci Melecjusza w 381 roku $^{79}$.

W relacjach obu Kościołów tym razem nie odwoływano się ani do szczególnych przywilejów ani też nie przywoływano wymyślnych argumentów. Być może ton biskupa Rzymu Liberiusza jest bardziej oficjalny, a biskupów Wschodu bardziej koncyliacyjny, ale to mogło wynikać z sytuacji: biskupi Wschodu szukali wsparcia. Natomiast do biskupa Rzymu zwracali się tak samo, jak zwracali się do innych biskupów, co ważniejszych stolic na Zachodzie. Była to zwyczajowa praktyka szukania „communio” $z$ innymi Kościołami lokalny$\mathrm{mi}$, stosowana wówczas powszechnie ${ }^{80}$.

Następcą Melecjusza zostal Flawian. Nie wszyscy jednak uznali ten wybór. Historyk Sozomen napisał: „niesłychanie oburzony był biskup rzymski i cały episkopat na Zachodzie. I do Paulina, jako do biskupa Antiochii, wysłali przyjęte w kościelnym zwyczaju listy, które nazywają «synodalnymi»" ${ }^{81}$. W tym czasie biskupem Rzymu był już Damazy (366-384). Jego linia postępowania była kontynuacją linii poprzednika, choć nie ulega wątpliwości, że w stosunkach $\mathrm{z}$ innymi stolicami miał świadomość swej wyjątkowej pozycji. Była ona tym mocniejsza, że cesarz Teodozjusz edyktem Cunctos populos ${ }^{82}$ nakazał poddanym - jak to ujmie historyk Sozomen - „pojmować wiarę w ujęciu, które

\footnotetext{
${ }^{76}$ Szerzej zob. Simonetti, La crisi ariana, dz. cyt., s. 361-363.

77 Por. Socrates, HE IV 12.

${ }^{78}$ Por. M. Simonetti, Melezio di Antiochia, DPAC II 2206.

79 Wiadomosć o tym, że „Rzym uznał Melecjusza oraz udzielił mu communio”, jak podaje E. Przekop (dz. cyt., s. 136), nie znajduje potwierdzenia w źródłach.

${ }^{80}$ Szerzej zob. Przekop, dz. cyt., s. 110nn.

81 Sozomenos, HE VII 11, PG 67, 1441C, Kazikowski s. 471.

82 Por. Codex Thedosianus XVI 1, 2.
} 
przekazał Rzymianom Piotr, książę apostołów; aby ją zachowywali tak, jak ją zachowywał Damazy, biskup Rzymu"83.

Do załagodzenia sytuacji doszło za czasów następcy Damazego Syrycjusza, ale główną zasługę w tym względzie należy przyznać Flawianowi. To on poruszając „niebo i ziemię" zdołał pojednać się wpierw z Teofilem biskupem Aleksandrii, a następnie $\mathrm{z}$ biskupem Rzymu. Według historyka Sokratesa tym sposobem „Flawian odzyskał łączność z Kościołem" ${ }^{84}$. Nie oznaczało to jednak pełnego zakończenia „schizmy antiocheńskiej”, bo zwolennicy Paulina nigdy nie uznali biskupa Flawiana. Podziały te zakończyly się dopiero około 415 roku $^{85}$.

W świetle tego, co dotychczas zostało przedstawione, można pokusić się o kilka wniosków. Nie podlega dyskusji istotna rola biskupa Antiochii, która już w okresie przednicejskim była uznawana nie tylko na Wschodzie, ale też z perspektywy Rzymu, jak też innych wielkich stolic chrześcijańskich. Ten stan rzeczy został prawnie usankcjonowany na soborze w Nicei w 325 roku. To, co tam zostało zapisane, choć w bardzo ogólnej formule, stanie się potem punktem odniesienia. „Kanon $6 \mathrm{z}$ Nicei był prawną podstawą dla rozwoju właściwego patriarchatu w IV i V wieku"86.

Biskup Antiochii od samego początku cieszył się pewnymi uprawnieniami wobec biskupów zamieszkujących jego region, co nie pochodziło z żadnego odgórnego nadania czy też zrzeczenia się uprawnień podległych podmiotów, ale na mocy zwyczaju. Dokonywało się to za cichym przyzwoleniem pozostałych stolic, w tym także Rzymu. Autorytet biskupa Antiochii wyrażał się w jego władzy jurydycznej w sprawach dotyczących „karności kościelnej, liturgii oraz wiary" $" 87$. W tym względzie rola tego biskupa była analogiczna do tej, jaką spełniali biskupi Rzymu i Aleksandrii.

Dopiero od IV wieku na pozycje patriarchatów i zakres wladzy biskupów tych stolic zaczęły zwracać uwagę synody, tak partykularne jak też powszechne. Wtedy też zaczyna się zwracać uwagę na racje uzasadniające ten stan rzeczy. Wśród argumentów pojawiło się odwołanie do apostolskich korzeni i „apostolskiego charakteru" poszczególnych stolic patriarchalnych. W relacjach antiocheńskorzymskich na tego rodzaju argumenty częściej powoływał się biskup Rzymu ${ }^{88}$.

Kontakty patriarchy Antiochii z biskupem Rzymu dotyczyły w głównej mierze spraw personalnych. Najczęściej chodziło o powiadomienie biskupa

${ }^{83}$ Sozomenos HE VII 4, PG 67, 1424, Kazikowski s. 458. Wyjątkowa pozycja biskupa Rzymu została osłabiona nieco edyktem z $381 \mathrm{r}$, w którym zostali wymienieni także inni biskupi jako wzorce ortodoksji, por. Codex Thedosianus XVI 5, 6 .

84 Socrates, HE V 15, PG 67, 6047, Kazikowski s. 415.

85 Por. J. Szymusiak. Antiochenska schizma, EK I 646.

86 W. de Vries, Rom und die Patriarchate des Ostens, Freiburg - München 1963, 8.

87 Lahm, dz. cyt., s. 125.

88 Po raz pierwszy mial to uczynić synod rzymski w 382 roku, por. Przekop, dz. cyt. s. 68. 
Rzymu „listem synodalnym” o wyborze danej osoby na tron w Antiochii. Wybór na ogół odbywał się bez jakiejkolwiek interwencji Rzymu. „Podstawowa funkcja papiestwa sprowadzała się wówczas nie do tego, by zajmować się licznymi kwestiami związanymi ze sprawowaniem urzędów, ale do pozostawania rozstrzygającym centrum komunii" ${ }^{89}$. Były jednak przypadki, że wybór taki napotykał na przeszkody. W Rzymie wówczas szukano poparcia i w tej sytuacji biskup Rzymu poprzez aprobatę lub jej brak mógł wpływać na obsadę tej stolicy. W okresie nas interesującym biskup Rzymu odmawiał uznania „communio" z tymi biskupami Antiochii, którzy zostali wybrani bądź to z naruszeniem procedury, bądź też nie mieścili się w ortodoksji Kościoła ${ }^{90}$. Ten sposób reagowania, a tym samym wpływ, nie zawsze był w pełni skuteczny, co nie oznacza, że się ze stanowiskiem biskupa Rzymu w ogóle nie liczono.

Interwencje Rzymu w inne obszary władzy patriarchy były bardzo rzadkie. Biskup Antiochii we własnym zakresie regulował sprawy związane $z$ liturgią i dyscypliną kościelną na swoim terenie. Rzym, jak się wydaje, w te dziedziny nie ingerował i to była ogólna norma dla wszystkich wschodnich patriarchatów w całym pierwszym tysiącleciu ${ }^{91}$. Taka była praktyka - przynajmniej do końca IV wieku. Natomiast trudno pokusić się o wskazanie uzasadnień doktrynalnych, gdyż źródeł ku temu jest po prostu za mało.

\section{RAPPORTI FRA IL PATRIARCATO ANTIOCHENO E LA ROMA PAPALE NEL I-IV SECOLO}

(Riassunto)

Il vescovo antiocheno fin dall'inizio del cristianesimo svolgeva un ruolo importane nella regione orientale ed in tutta la Chiesa antica. L'importanza di questa sede vescovile risultava dalla sua provenienza (fondata dagli Apostoli) e dal fatto d'essere un capoluogo dell'Oriente. Il concilio di Nicea riconferma ad Antiochia i privilegi di una sede principale, insieme ad Alessandria, Roma e Gerusalemme. Fino alla „scisma antiochena" del IV secolo le reciproci rapporti fra il patriarcato antiocheno ed il vecovo di Roma furono pieni di rispetto. Durante la scisma i vescovi ortodossi antiocheni cercavano l'appoggio a Roma. Il papa si sentiva obbligato ad intervenire ma con scarsi successi. Nell'articolo viene esaminata la natura ed i motivi degli interventi del vescovo di Roma negli affari antiocheni.

\footnotetext{
${ }^{89}$ De Vries, dz. cyt., s. 13.

${ }^{90}$ Por. Przekop, dz, cyt., s. 135-137.

91 Por. De Vries, dz. cyt., s. 20-22.
} 